\title{
PENGARUH SIKAP KEWIRAUSAHAAN, NORMA SUBYEKTIF, DAN EFIKASI DIRI TERHADAP PERILAKU BERWIRAUSAHA MELALUI INTENSI BERWIRAUSAHA MAHASISWA
}

\author{
Novita Nurul Islami, Universitas Jember \\ novitanurulislami@yahoo.co.id
}

\begin{abstract}
ABSTRAK
Penelitian ini bertujuan untuk menganalisis pengaruh sikap kewirausahaan, norma subyektif, dan efikasi diri terhadap perilaku berwirausaha melalui intensi berwirausaha mahasiswa. Populasi dalam penelitian ini adalah mahasiswa S1 angkatan tahun 2010 dan 2011 Program Studi Pendidikan Ekonomi FKIP Universitas Jember tahun akademik 2013/2014 sebanyak 174 orang dengan jumlah sampel sebanyak 121 orang. Adapun teknik pengumpulan data yang digunakan yaitu angket, wawancara, dan dokumentasi. Metode analisis menggunakan Structural Equation Modeling (SEM). Hasil penelitian menunjukkan bahwa sikap kewirausahaan dan efikasi diri berpengaruh signifikan terhadap intensi berwirausaha. Sikap kewirausahaan dan efikasi diri berpengaruh signifikan terhadap perilaku berwirausaha. Sedangkan, norma subyektif tidak berpengaruh langsung baik terhadap intensi berwirausaha maupun perilaku berwirausaha. Intensi berwirausaha juga tidak berpengaruh langsung terhadap perilaku berwirausaha. Demikian juga dengan sikap kewirausahaan, norma subyektif dan efikasi diri juga tidak berpengaruh signifikan terhadap perilaku berwirausaha melalui intensi berwirausaha.
\end{abstract}

Kata kunci: sikap kewirausahaan, norma subyektif, efikasi diri, intensi berwirausaha, perilaku berwirausaha

\section{ABSTRACT}

This study analyze the influence of the attitude of entrepreneurship, a subjective norm and efficacy themselves against entrepreneurship behaviour through students' entrepreneurial intention. The population of this study are the 2010 and 2011 generations of economic education students FKIP Jember University in the academic year 2013/2014 as many as 174 people with the total samples 121 people. The data collection techniques using questionnaires, interviews, and documentation. The method of analysis using Structural Equation Modelling (SEM). The results showed that entrepreneurial attitude and self-efficacy significantly influence entrepreneurial intentions. Entrepreneurial attitude and self-efficacy significantly influence entrepreneurial behaviour. Whereas, subjective norm does not directly affect either the intention of entrepreneurship and entrepreneurial behaviour. Entrepreneurial intentions are also not directly influence the entrepreneurial behaviour. Likewise, an entrepreneurial attitude, subjective norm and self-efficacy also no significant effect on entrepreneurial behaviour intention through entrepreneurship.

Keywords: entrepreneurial attitudes, subjective norms, self-efficacy, entrepreneurial intention, entrepreneurship behaviour 


\section{PENDAHULUAN}

Di era globalisasi sekarang ini, persaingan dan tantangan semakin berat terutama pada bidang ekonomi yang tidak hanya persaingan ditingkat lokal, regional dan nasional, namun juga persaingan global dari berbagai negara yang siap untuk bersaing. Pada era ini, dibutuhkan para entrepreneur yang mampu menjawab tantangan dan peluang.

Hal tersebut didukung oleh Wibowo (2011) yang menerangkan bahwa menurut Joseph Schumpeter faktor yang paling menentukan dalam pertumbuhan ekonomi suatu negara adalah pengusaha yang mampu melakukan inovasi dan kreatifitas, dan hal yang sama juga dikemukakan oleh McClelland bahwa agar suatu negara menjadi makmur diperlukan sedikitnya $2 \%$ dari penduduknya yang menjadi pengusaha. Hal ini menunjukkan bahwa adanya pertumbuhan wirausaha akan membawa peningkatan perekonomian yang luar biasa bagi suatu Negara. Sehingga semakin banyak suatu Negara memiliki wirausaha, maka akan semakin meningkat perekonomiannya.

Perguruan tinggi sebagai institusi pendidikan ikut berpartisipasi aktif dan berperan serta dalam membangun ekonomi yang kini masih terpuruk. Berdasarkan kondisi objektif masyarakat khususnya perguruan tinggi sebagai penghasil SDM yang berkualitas, ternyata masih belum mampu menghasilkan lulusan yang siap berwirausaha mandiri. Adanya pembelajaran kewirausahaan dapat menjadi salah satu faktor pendorong pertumbuhan kewirausahaan disuatu negara.

Upaya pendidikan kewirausahaan mulai terlihat dilakukan oleh kalangan institusi pendidikan, termasuk Perguruan Tinggi. Kurikulum yang telah memasukkan pendidikan kewirausahaan atau mata kuliah kewirausahaan telah marak, namun demikian hasilnya masih belum seberapa terlihat. Berdasarkan kondisi tersebut, maka perguruan tinggi negeri maupun swasta juga memiliki tanggung jawab untuk ikut menyiapkan mahasiswanya menjadi wirausaha yang unggul agar tidak menggantungkan lowongan pekerjaan pada pihak lain.

Begitu juga dengan FKIP Universitas Jember, juga telah memasukkan mata kuliah kewirausahaan kedalam kurikulumnya. Mata kuliah kewirausahaan pada kurikulum Program Studi Pendidikan Ekonomi, FKIP Universitas Jember diajarkan pada semester VI dengan bobot 2 SKS. Berdasarkan studi pendahuluan yang dilakukan oleh peneliti, $40 \%$ mahasiswa Program Studi Pendidikan Ekonomi, FKIP Universitas Jember angkatan 2010 dan 2011 menyatakan bahwa mahasiswa lebih tertarik untuk menjadi pegawai atau karyawan dari pada berwirausaha, dan berwirausaha hanya menjadi alternatif jika mereka tidak segera mendapatkan pekerjaan. Sehingga, dapat diketahui bahwa ternyata kecenderungan perilaku untuk berwirausaha pada mahasiswa masih rendah. Fakta di atas menjadi salah satu alasan peneliti untuk mengetahui lebih lanjut tentang perilaku berwirausaha pada mahasiswa Program Studi Pendidikan Ekonomi, FKIP Universitas Jember.

Riset mengenai perilaku berwirausaha menjadi hal yang menarik bagi peneliti di berbagai negara. Riset mengenai perilaku berwirausaha berkembang dari berbagai perspektif yaitu mulai dari perpektif ekonomi, psikologi, dan sosiologi. Berbagai model juga dikembangkan dalam penelitian perilaku 
berwirausaha di antaranya Theory of Planned Behavior (TPB) oleh Ajzen dan Fishbein (Baron \& Byrne, 2004). Perbedaan dasar model yang mengacu pada Theory of Planned Behavior dengan model lainnya, model dasar Theory of Planned Behavior dianggap lebih baik dan kompleks dalam menjelaskan perilaku berwirausaha. Hasil riset dan model riset terdahulu menyajikan kesimpulan yang belum tentu sesuai dengan kondisi dan situasi dewasa ini di Indonesia. Masalah tersebut lebih mendorong penulis mencermati model perilaku berwirausaha pada mahasiswa.

Theory of Planned Behavior (TPB) merupakan pengembangan lebih lanjut dari Teori Tindakan Rasional. TPB menambahkan konstruk yang belum ada dalam Teori Tindakan Rasional, yaitu kontrol perilaku yang dipersepsi (perceived behavioral control) atau yang dikenal dengan efikasi diri. Konstruk ini ditambahkan dalam upaya memahami keterbatasan yang dimiliki individu dalam rangka melakukan perilaku tertentu. Dengan kata lain, dilakukan atau tidak dilakukannya suatu intensi dan perilaku tidak hanya ditentukan oleh sikap dan norma subjektif semata, tetapi juga efikasi diri. Menurut Theory of Planned Behavior (TPB) keputusan untuk menampilkan tingkah laku tertentu adalah hasil dari proses rasional yang diarahkan pada suatu tujuan tertentu dan mengikuti urutan-urutan berfikir (Baron \& Byrne, 2004). Perhatian utama dalam theory of planned behavior adalah pada intensi seseorang untuk melakukan suatu perilaku, karena intensi merupakan variabel antara yang menyebabkan terjadinya perilaku dari suatu sikap maupun variabel lainnya.

Secara umum, faktor anteseden intensi dapat diungkapkan melalui Theory Planned of Behavior (TPB) yaitu sikap, norma subjektif dan efikasi diri. Terbentuknya intensi dapat diterangkan dengan teori perilaku terencana yang mengasumsikan manusia selalu mempunyai tujuan dalam berperilaku (Baron \& Byrne, 2004). Teori ini menyebutkan bahwa intensi adalah fungsi dari tiga determinan dasar, yaitu sikap, norma subyektif, dan efikasi diri.

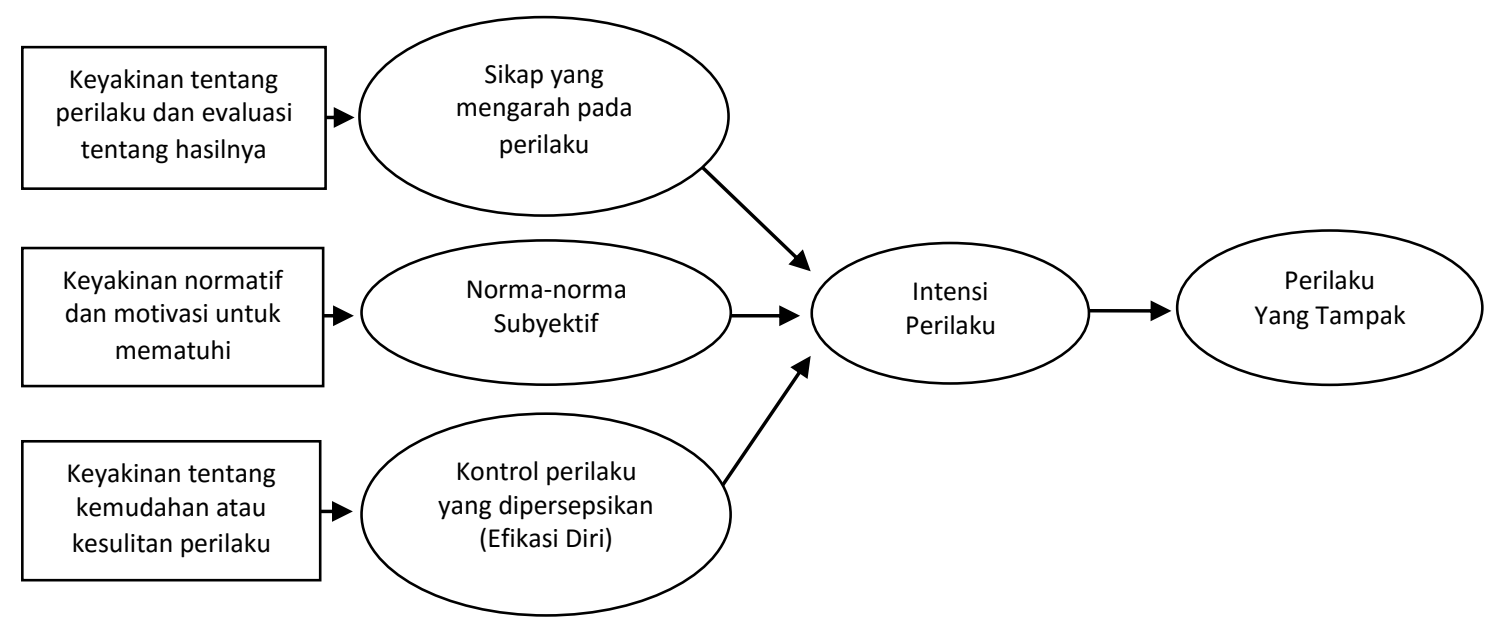

Gambar 1. The Theory of Planned Behavior (Ajzen \& Fishbein dalam Baron \& Byrne, 2004) 
Dalam konteks kewirausahaan menurut Andika dan Iskandarsyah (2012) menjabarkan bahwa menurut Gadaam sikap kewirausahaan yaitu kecenderungan untuk bereaksi secara afektif dalam menanggapi resiko yang akan dihadapi dalam suatu bisnis yang dapat diukur dengan skala sikap berwirausaha dengan indikator : 1) tertarik dengan peluang usaha, 2) berfikir kreatif dan inovatif, 3) pandangan positif mengenai kegagalan usaha, 4) memiliki jiwa kepemimpinan dan tanggung jawab, 5) suka menghadapi resiko dan tantangan.

Andika dan Iskandarsyah (2012) menjelaskan bahwa norma subyektif menurut Ramayah dan Harun dapat diukur dengan skala subjective norm dengan indikator: 1) keyakinan peran keluarga dalam memulai usaha, 2) keyakinan dukungan teman dalam usaha, 3) keyakinan dukungan dari dosen, 4) keyakinan dukungan dari pengusaha-pengusaha yang sukses, dan 5) keyakinan dukungan dalam usaha dari orang yang dianggap penting.

Dalam konteks kewirausahaan efikasi diri didefinisikan sebagai kekuatan keyakinan seseorang bahwa dia akan mampu dan berhasil melakukan berbagai peran dalam berwirausaha. Sedangkan menurut Andika dan Iskandarsyah (2012) berdasarkan pendapat Gadaam efikasi diri dalam kaitannya dengan berwirausaha yaitu kepercayaan (persepsi) individu mengenai kemampuan untuk membentuk suatu perilaku berwirausaha yang dapat diukur dengan indikator : 1) kepercayaan diri akan kemampuan mengelola usaha, 2) kepemimpinan sumber daya manusia, 3) kematangan mental dalam usaha, dan 4) merasa mampu memulai usaha.

Andika dan Iskandarsyah (2012) menjabarkan definisi dan indikator intensi berwirausaha menurut Ramayah dan Harun bahwa intensi berwirausaha merupakan tendensi keinginan individu untuk melakukan tindakan wirausaha dan diukur dengan skala entrepreneur intention dengan indikator: 1) memilih jalur usaha dari pada bekerja pada orang lain, 2) memilih karir sebagai wirausahawan, 3) membuat perencanaan untuk memulai usaha, 4) meningkatkan status sosial sebagai wirausaha, 5) mendapatkan pendapatan yang lebih baik dengan berwirausaha.

Sedangkan, perilaku berwirausaha menurut Wijaya (2008) merupakan tindakan yang tampak atau pernyataan lisan mengenai perilaku berwirausaha yang dapat diukur dengan skala perilaku berwirausaha, dengan indikator: 1) keputusan wirausaha, 2) tindakan nyata telah menjalankan usaha, dan 3) pernyataan rencana pengembangan usaha yang ada.

Berdasarkan pemikiran dan kajian empiris di atas, maka penelitian difokuskan untuk menganalisis pengaruh sikap kewirausahaan terhadap intensi berwirausaha mahasiswa, pengaruh sikap kewirausahaan terhadap perilaku berwirausaha mahasiswa, pengaruh norma subyektif terhadap intensi berwirausaha mahasiswa, pengaruh norma subyektif terhadap perilaku berwirausaha mahasiswa, pengaruh efikasi diri terhadap intensi berwirausaha mahasiswa, pengaruh efikasi diri terhadap perilaku berwirausaha mahasiswa, pengaruh intensi berwirausaha terhadap perilaku berwirausaha mahasiswa, menganalisis apakah intensi berwirausaha memediasi sikap kewirausahaan terhadap perilaku berwirausaha mahasiswa, apakah intensi berwirausaha memediasi norma subyektif terhadap perilaku berwirausaha mahasiswa, apakah intensi berwirausaha memediasi efikasi diri terhadap perilaku berwirausaha mahasiswa. 


\section{METODE PENELITIAN}

Jenis penelitian ini adalah penelitian eksplanatori (explanatory research) yaitu suatu penelitian untuk mencari dan menjelaskan hubungan kausal antar variabel (Sukmadinata, 2012). Objek penelitian ini meliputi variabel-variabel yang diteliti yaitu sikap kewirausahaan, norma subyektif dan efikasi diri, perilaku berwirausaha dan intensi berwirausaha mahasiswa Program Studi Pendidikan Ekonomi FKIP Universitas Jember. Penelitian ini menganalisis pengaruh sikap kewirausahaan, norma subyektif, dan efikasi diri terhadap perilaku berwirausaha melalui intensi berwirausaha mahasiswa Program Studi Pendidikan Ekonomi FKIP Universitas Jember.

Populasi dalam penelitian ini yaitu mahasiswa S1 angkatan tahun 2010 dan 2011 Program Studi Pendidikan Ekonomi FKIP Universitas Jember tahun akademik 2013/2014 sebanyak 174 orang, sedangkan jumlah sampel yaitu sebanyak 121 orang. Teknik sampling yang digunakan dalam penelitian ini adalah propotional random sampling. Propotional random sampling adalah teknik pengambilan anggota sampel dari populasi dilakukan secara acak tanpa memperhatikan strata yang ada dalam populasi (Sugiyono, 2011). Dipilihnya mahasiswa angkatan 2010 dan 2011 dengan pertimbangan bahwa mahasiswa angkatan sebagian besar sudah menempuh mata kuliah kewirausahaan, karena mata kuliah kewirausahaan ditawarkan pada semester VI.

Adapun teknik pengumpulan data yang digunakan yaitu angket, wawancara, dan dokumentasi. Sedangkan sumber data yang digunakan dalam penelitian ini diambil dari dua kategori sumber, yaitu sumber primer dan sumber sekunder. Data primer berupa data yang diperoleh langsung dari setiap responden yang terpilih sebagai sampel melalui pengisian angket penelitian. Data sekunder berupa data yang diperoleh dari dokumen-dokumen terkait dengan variabel yang diamati untuk mendukung pernyataan dan teori yang telah dibangun, sehingga dapat menunjang penelitian.

Variabel dalam penelitian ini terdiri dari variabel eksogen dan endogen. Variabel eksogen dalam penelitian ini yaitu sikap kewirausahaan, norma subyektif dan efikasi diri. Sedangkan variabel endogennya yaitu intensi berwirausaha dan perilaku berwirausaha dengan menggunakan analisis statistik deskriptif dan inferensial. Analisis statistik deskriptif dilakukan dengan mendeskripsikan karakteristik variabel yang diteliti. Sedangkan analisis statistik inferensial dilakukan untuk menganalisis hubungan antarvariabel dan adanya hubungan asimetris antar kelompok variabel yang berhubungan baik langsung maupun tidak langsung. Dengan demikian, penelitian ini dirancang dengan menggunakan teknik analisis multivariat dengan menggunakan teknik analisis structural equation modeling (SEM).

\section{HASIL DAN PEMBAHASAN}

Rata-rata nilai konstruk sikap kewirausahaan mahasiswa sebesar 4,170 yang berarti dalam kategori baik. Artinya, sikap kewirausahaan mahasiswa baik yaitu tergambar dari cukup tingginya ketertarikan mahasiswa dengan peluang usaha, berfikir kreatif dan inovatif, memiliki pandangan positif mengenai kegagalan 
usaha, memiliki jiwa kepemimpinan dan tanggung jawab, serta suka menghadapi resiko dan tantangan.

Konstruk norma subyektif memiliki nilai rata-rata sebesar 4,121 yang berarti dalam kategori baik. Artinya, norma subyektif memberikan peran cukup baik yang tergambar dari cukup tingginya peran norma subyektif yaitu keyakinan dukungan keluarga, teman, dosen dan orang-orang yang dianggap penting dalam memulai usaha.

Rata-rata nilai konstruk efikasi diri adalah 4,12 yang berarti dalam kategori baik. Artinya, mahasiswa memiliki nilai efikasi diri yang cukup baik yang tergambar dengan cukup tingginya kepercayaan diri akan kemampuan mengelola usaha, kepemimpinan sumber daya manusia, kematangan mental dalam usaha dan merasa mampu memulai usaha.

Intensi berwirausaha memiliki nilai dalam kategori baik sebesar 4,072 yang digambarkan dari mahasiswa lebih memilih jalur berwirausaha sendiri dari pada bekerja pada orang lain, memilih karir sebagai wirausahawan, telah membuat perencanaan untuk memulai usaha dan berkeyakinan dapat mendapatkan pendapatan yang lebih baik dengan berwirausaha.

Sedangkan perilaku berwirausaha memiliki nilai rata-rata dengan kategori sedang yaitu 3,312. Artinya sebagian dari mahasiswa masih sedang, hasil temuan menunjukkan bahwa perilaku berwirausaha paling rendah dipengaruhi oleh indikator ke dua yaitu tindakan nyata telah melakukan usaha. Hal ini menunjukkan bahwa sebagian besar mahasiswa masih belum memiliki usaha sendiri.

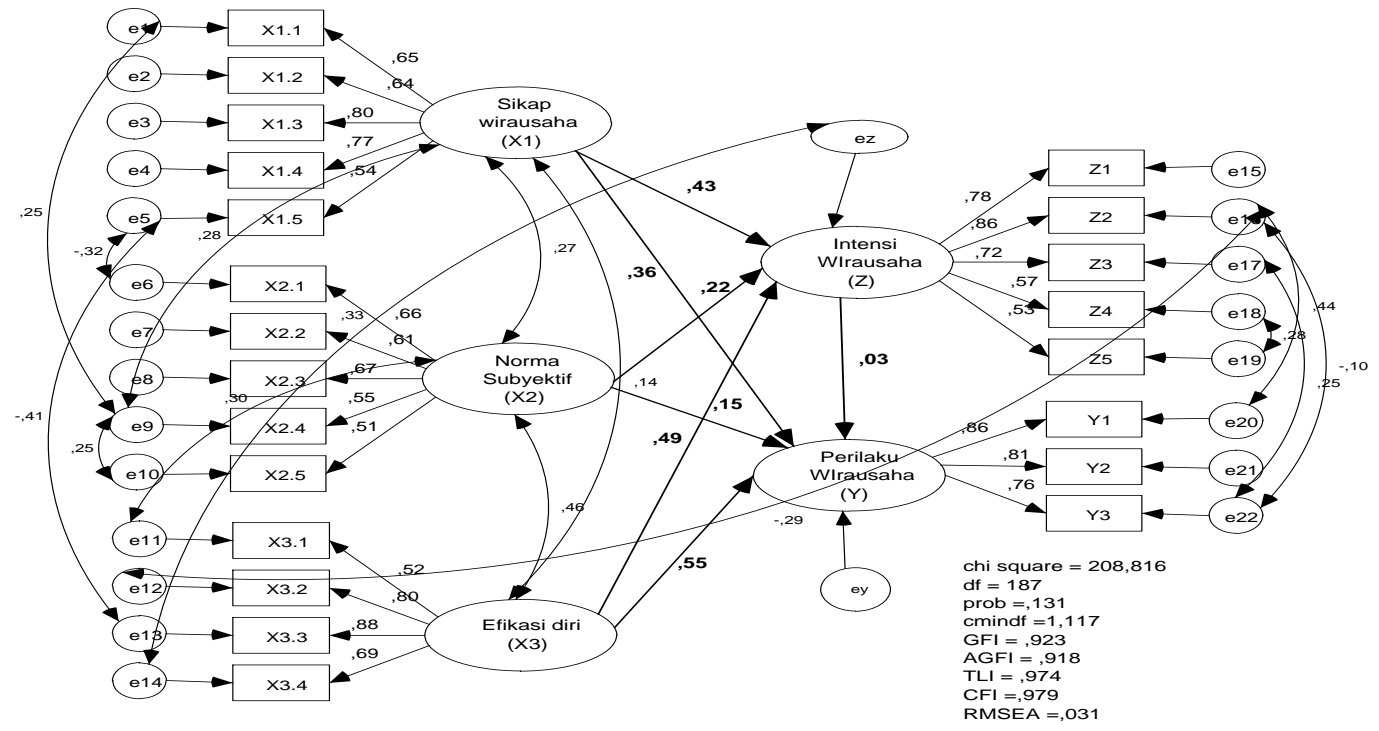

\section{Gambar 2. Hasil Pengujian Struktural Setelah Modifikasi Indeks}

Uji kecocokan model pengukuran dilakukan dengan menggunakan model CFA yang terdiri atas dua uji kecocokan model pengukuran yaitu CFA eksogen untuk menguji konstruk sikap wirausaha, norma subyektif, dan efikasi diri dan CFA endogen untuk menguji intensi wirausaha dan perilaku wirausaha. Hasil pengujian pengukuran dengan menggunakan CFA baik eksogen ataupun endogen menunjukkan secara keseluruhan model dapat diterima karena terdapat kesesuaian model yang dibangun dengan persyaratan model fit. Analisis SEM dalam 
penelitian ini memeperoleh hasil pengujian struktural yang ditujukan dalam gambar 2.

Hasil pengujian hipotesis dilakukan setelah melalui serangkaian tahapan pengujian analisis SEM untuk mengetahui hubungan antarvariabel endogen dan eksogen sesuai dengan hipotesis yang telah diajukan. Dalam penelitian ini penulis mengajukan sepuluh hipotesis, adapun hasil pengujian sepuluh hipotesis yang diajukan disajikan pada tabel 1 sebagai berikut.

\section{Tabel 1.}

Hasil Pengujian Hipotesis Model Persamaan Struktural

\begin{tabular}{|c|c|c|c|c|c|c|}
\hline Hipotesis & \multicolumn{3}{|c|}{ Pengaruh } & Koefisien & C.R. & Keterangan \\
\hline $\mathrm{H}_{1}$ & $\begin{array}{l}\text { Sikap } \\
\text { wirausaha }\left(\mathrm{X}_{1}\right)\end{array}$ & $\rightarrow$ & $\begin{array}{l}\text { Intensi } \\
\text { berwirausaha }(\mathrm{Z})\end{array}$ & 0,429 & 2,611 & Signifikan \\
\hline $\mathrm{H}_{2}$ & $\begin{array}{l}\text { Sikap } \\
\text { wirausaha }\left(\mathrm{X}_{1}\right)\end{array}$ & $\rightarrow$ & $\begin{array}{l}\text { Perilaku } \\
\text { berwirausaha (Y) }\end{array}$ & 0,355 & 2,459 & Signifikan \\
\hline $\mathrm{H}_{3}$ & $\begin{array}{l}\text { Norma } \\
\text { subyektif }\left(\mathrm{X}_{2}\right)\end{array}$ & $\rightarrow$ & $\begin{array}{l}\text { Intensi } \\
\text { berwirausaha }(\mathrm{Z})\end{array}$ & 0,216 & 0,926 & $\begin{array}{c}\text { Tidak } \\
\text { Signifikan }\end{array}$ \\
\hline $\mathrm{H}_{4}$ & $\begin{array}{l}\text { Norma } \\
\text { subyektif }\left(\mathrm{X}_{2}\right)\end{array}$ & $\rightarrow$ & $\begin{array}{l}\text { Perilaku } \\
\text { berwirausaha (Y) }\end{array}$ & 0,152 & 0,504 & $\begin{array}{c}\text { Tidak } \\
\text { Signifikan }\end{array}$ \\
\hline $\mathrm{H}_{5}$ & $\begin{array}{l}\text { Efikasi diri } \\
\left(\mathrm{X}_{3}\right)\end{array}$ & $\rightarrow$ & $\begin{array}{l}\text { Intensi } \\
\text { berwirausaha }(\mathrm{Z})\end{array}$ & 0,489 & 3,197 & Signifikan \\
\hline $\mathrm{H}_{6}$ & $\begin{array}{l}\text { Efikasi diri } \\
\left(\mathrm{X}_{3}\right)\end{array}$ & $\rightarrow$ & $\begin{array}{l}\text { Perilaku } \\
\text { berwirausaha }(\mathrm{Y})\end{array}$ & 0,553 & 3,599 & Signifikan \\
\hline $\mathrm{H}_{7}$ & $\begin{array}{l}\text { Intensi } \\
\text { berwirausaha } \\
(\mathrm{Z})\end{array}$ & $\rightarrow$ & $\begin{array}{l}\text { Perilaku } \\
\text { berwirausaha }(\mathrm{Y})\end{array}$ & 0,031 & 0,283 & $\begin{array}{l}\text { Tidak } \\
\text { Signifikan }\end{array}$ \\
\hline $\begin{array}{l}\text { Hipotesis } \\
\text { tidak } \\
\text { Langsung }\end{array}$ & \multicolumn{4}{|c|}{ Pengaruh } & $\begin{array}{c}\text { t } \\
\text { hitung }\end{array}$ & Keterangan \\
\hline $\mathrm{H}_{8}$ & \multicolumn{4}{|c|}{$\begin{array}{l}\text { Sikap Kewirausahaan }\left(\mathrm{X}_{1}\right) \text { terhadap Perilaku } \\
\text { Berwirausaha }(\mathrm{Y}) \text { melalui IntensI Berwirausaha }(\mathrm{Z})\end{array}$} & 0,2149 & $\begin{array}{c}\text { Tidak } \\
\text { Signifikan }\end{array}$ \\
\hline $\mathrm{H}_{9}$ & \multicolumn{4}{|c|}{$\begin{array}{l}\text { Norma Subyektif }\left(\mathrm{X}_{2}\right) \text { terhadap Perilaku Berwirausaha } \\
(\mathrm{Y}) \text { melalui Intensi Berwirausaha }(\mathrm{Z})\end{array}$} & 0,1453 & $\begin{array}{c}\text { Tidak } \\
\text { Signifikan }\end{array}$ \\
\hline $\mathrm{H}_{10}$ & \multicolumn{4}{|c|}{$\begin{array}{l}\text { Efikasi Diri }\left(\mathrm{X}_{3}\right) \text { terhadap Perilaku Berwirausaha }(\mathrm{Y}) \\
\text { melalui Intensi Berwirausaha }(\mathrm{Z})\end{array}$} & 0,2179 & $\begin{array}{c}\text { Tidak } \\
\text { Signifikan }\end{array}$ \\
\hline
\end{tabular}

Hipotesis pertama yang diajukan dalam penelitian ini diterima. Berdasarkan hasil penelitian diperoleh hasil yang menunjukkan bahwa sikap kewirausahaan mempunyai pengaruh yang signifikan terhadap intensi berwirausaha mahasiswa. Hasil tersebut dapat dilihat dari nilai koefisien jalur sikap kewirausahaan $\left(\mathrm{X}_{1}\right)$ terhadap intensi berwirausaha (Z). Hal ini berarti semakin baik sikap kewirausahaan mahasiswa Program Studi Pendidikan Ekonomi FKIP Universitas Jember, maka akan semakin baik pula tingkat intensi berwirausahanya.

Hasil penelitian ini mendukung hasil penelitian-penelitian sebelumnya, di antaranya yang dilakukan oleh Andika dan Iskandarsyah (2012) yang menerangkan bahwa sikap merupakan faktor internal yang menjadi salah satu faktor paling dominan dibandingkan dengan norma subyektif dan efikasi diri yang mempengaruhi intensi berwirausaha mahasiswa. Selain itu, Suharti dan Hani (2011) juga menemukan pengaruh yang signifikan antara sikap dan intensi berwirausaha. 
Dilain sisi, hasil penelitian ini juga mendukung penelitian lain yang dilakukan oleh Dwijayanti (2012) yang menerangkan bahwa sikap dapat memberikan sumbangan terhadap peningkatan intensi berwirausaha pada mahasiswa. Dan penelitian Urban, Jurie, dan Rina (2008) yang menemukan bahwa sikap berpengaruh signifikan terhadap intensi berwirausaha pada penduduk etnis yang berbeda di Afrika Selatan.

Sikap kewirausahaan berpengaruh signifikan terhadap intensi berwirausaha mahasiswa Program Studi Pendidikan Ekonomi FKIP Universitas Jember didukung oleh temuan pada variabel sikap kewirausahaan dalam penelitian ini lebih dominan didukung oleh indikator memiliki jiwa kepemimpinan dan tanggungjawab. Hal ini dapat ditunjukkan dari temuan bahwa sebagian besar mahasiswa selalu ingin menyelesaikan pekerjaan lebih cepat dari waktu yang ditetapkan, mahasiswa selalu mempunyai kemauan keras untuk mencapai segala sesuatu yang diinginkan, mahasiswa mementingkan perencanaan merupakan hal penting untuk mendapatkan hasil usaha yang optimal, mahasiswa selalu membuat perencanaan pada setiap aktivitas yang dilaksanakan, mahasiswa selalu bertanggungjawab terhadap semua pekerjaan yang dilakukan, dan mahasiswa selalu menghargai hasil kerja orang lain.

Selain itu, juga didukung oleh temuan pada variabel intensi berwirausaha paling dominan didukung oleh indikator kelima yaitu ingin mendapatkan pendapatan yang lebih baik dengan wirausaha. Hal ini dapat ditunjukkan dari hasil temuan bahwa sebagian besar mahasiswa ingin mendapatkan pendapatan yang lebih baik dengan berwirausaha. Hasil temuan tersebut menunjukkan bahwa sikap kewirausahaan terbukti dapat memberikan sumbangan positif terhadap potensi munculnya intensi berwirausaha pada mahasiswa. Hal tersebut sesuai dengan pendapat Dwijayanti (2012) yang menerangkan bahwa sikap dapat memberi sumbangan terhadap peningkatan intensi berwirausaha pada mahasiswa.

Sehingga, dapat disimpulkan bahwa dalam penelitian ini teori Ajzen dan Fishbein "The Theory of Planned Behavior" (dalam Baron \& Byrne, 2004) yang mengungkapkan bahwa sikap merupakan salah satu prediktor yang mempengaruhi intensi tertentu dapat terbukti. Sikap kewirausahaan dapat terbukti menjadi prediktor yang mempengaruhi intensi berwirausaha pada mahasiswa Program Studi Pendidikan Ekonomi FKIP Universitas Jember.

Hipotesis kedua yang diajukan dalam penelitian ini diterima. Berdasarkan hasil penelitian diperoleh hasil yang menunjukkan bahwa sikap kewirausahaan mempunyai pengaruh yang signifikan terhadap perilaku berwirausaha mahasiswa. Hasil tersebut dapat dilihat dari nilai koefisien jalur sikap kewirausahaan $\left(\mathrm{X}_{1}\right)$ terhadap perilaku berwirausaha (Y). Hal ini berarti semakin baik sikap kewirausahaan mahasiswa Program Studi Pendidikan Ekonomi FKIP Universitas Jember maka akan semakin baik pula tingkat perilaku berwirausahanya.

Hasil penelitian ini mendukung hasil penelitian sebelumnya yang dilakukan oleh Wijaya (2008) yang menerangkan bahwa sikap berwirausaha merupakan salah satu prediktor yang berpengaruh positif terhadap perilaku berwirausaha. Namun bedanya Wijaya melakukan penelitian pada pelaku usaha yaitu pada UKM DIY dan Jawa Tengah. Sedangkan pada penelitian ini dilakukan pada tingkat pelajar yaitu mahasiswa, sehingga tentunya akan memberikan hasil yang berbeda pula. 
Sikap kewirausahaan berpengaruh signifikan terhadap perilaku berwirausaha mahasiswa Program Studi Pendidikan Ekonomi FKIP Universitas Jember didukung oleh temuan pada variabel sikap kewirausahaan dalam penelitian ini paling dominan didukung oleh indikator keempat yaitu memiliki jiwa kepemimpinan dan tanggungjawab. Hal ini dapat ditunjukkan dari temuan bahwa sebagian besar mahasiswa selalu ingin menyelesaikan pekerjaan lebih cepat dari waktu yang ditetapkan, mahasiswa selalu mempunyai kemauan keras untuk mencapai segala sesuatu yang diinginkan, mahasiswa mementingkan perencanaan merupakan hal penting untuk mendapatkan hasil usaha yang optimal, mahasiswa selalu membuat perencanaan pada setiap aktivitas yang dilaksanakan, mahasiswa selalu bertanggungjawab terhadap semua pekerjaan yang dilakukan, dan mahasiswa selalu menghargai hasil kerja orang lain.

Selain itu, juga didukung oleh temuan pada variabel perilaku berwirausaha paling dominan didukung oleh indikator ketiga yaitu rencana pengembangan usaha yang ada. Hal ini dapat ditunjukkan dari hasil temuan bahwa sebagian dari mahasiswa sudah merencanakan untuk mengembangkan usaha yang dimiliki untuk kedepannya.

Melihat responden pada penelitian ini masih dalam tingkat pelajar tentunya hasilnya tidak akan setinggi jika responden sudah pada tingkat pelaku usaha. Rata-rata mahasiswa menekuni wirausaha dibidang penjualan. Aneka produk yang dijual, di antaranya: pulsa, pakaian, makanan dan lain-lain. Sebagian ada juga yang menekuni bisnis MLM (Multi Level Marketing). Meskipun sebagian besar responden belum memutuskan untuk berwirausaha. Namun, hal tersebut sudah dapat dijadikan bekal yang bisa diharapkan dimasa depan untuk terjun di dunia kerja utamanya, karena tidak menutup kemungkinan mahasiswa kelak berkesempatan diserap oleh lapangan kerja non keguruan.

Hasil temuan tersebut menunjukkan bahwa sikap kewirausahaan terbukti dapat memberikan sumbangan positif terhadap potensi munculnya perilaku berwirausaha pada mahasiswa. Oleh karena itu, menurut Thomas dan Znaniecki (dalam Wawan \& Dewi, 2011) menerangkan bahwa melalui sikap, kita dapat memahami proses kesadaran yang menentukan tindakan nyata yang mungkin dilakukan individu dalam kehidupan sosialnya.

Sehingga, dapat disimpulkan bahwa dalam penelitian ini teori Ajzen dan Fishbein "The Theory of Planned Behavior" (dalam Baron \& Byrne, 2004) yang mengungkapkan bahwa sikap berwirausaha adalah salah satu elemen penting yang dapat mempengaruhi perilaku berwirausaha terbukti. Sikap kewirausahaan dapat terbukti menjadi prediktor yang mempengaruhi perilaku berwirausaha pada mahasiswa Program Studi Pendidikan Ekonomi FKIP Universitas Jember.

Hipotesis ketiga yang diajukan dalam penelitian ini ditolak. Berdasarkan hasil penelitian diperoleh hasil yang menunjukkan bahwa norma subyektif tidak terbukti mempunyai pengaruh yang signifikan terhadap intensi berwirausaha mahasiswa. Hasil tersebut dapat dilihat dari nilai koefisien jalur norma subyektif $\left(\mathrm{X}_{2}\right)$ terhadap intensi berwirausaha $(\mathrm{Z})$. Hal ini berarti bahwa norma subyektif mahasiswa Program Studi Pendidikan Ekonomi FKIP Universitas Jember ternyata tidak dapat mempengaruhi tingkat intensi berwirausahanya.

Hasil penelitian ini bertentangan dengan penelitian-penelitian sebelumnya yaitu di antaranya penelitian dari Andika dan Iskandarsyah (2012) yang menemukan bahwa norma subyektif berpengaruh signifikan terhadap intensi 
berwirausaha mahasiswa. Penelitian lain dari Endi Sarwoko (2011) yang juga menyimpulkan bahwa intensi berwirausaha dipengaruhi oleh norma subyektif dimana pengaruhnya positif. Dan penelitian yang dilakukan oleh Dwijayanti (2012) yang juga menyimpulkan bahwa norma subyektif berpengaruh signifikan terhadap intensi berwirausaha mahasiswa.

Norma subyektif tidak berpengaruh signifikan terhadap intensi berwirausaha. Temuan dalam penelitian ini indikator pada variabel norma subyektif rata-rata memiliki sumbangan rendah terhadap variabel norma subyektif, di antaranya paling rendah dipengaruhi oleh indikator kelima yaitu keyakinan dukungan dari orang yang dianggap penting. Hal ini dapat ditunjukkan dari hasil temuan bahwa hanya sebagian kecil mahasiswa saja yang sering mengikuti seminar yang memberikan motivasi dan pengetahuan kewirausahaan yang diadakan oleh para pengusaha atau lembaga-lembaga yang bergerak di bidang wirausaha.

Selain itu, juga didukung oleh temuan bahwa pada variabel intensi berwirausaha paling rendah dipengaruhi oleh indikator ketiga yaitu melakukan perencanaan untuk memulai usaha. Hal ini dapat ditunjukkan dari hasil temuan bahwa sebagian mahasiswa mempunyai gambaran tentang modal dasar berwirausaha, mahasiswa memiliki pengetahuan tentang lokasi strategis berwirausaha berdasarkan pengamatan, mahasiswa memiliki rencana yang jelas untuk menekuni bidang usaha tertentu dimasa mendatang, keinginan berwirausaha telah didukung oleh perencanaan yang matang, dan mahasiswa memiliki keyakinan dapat mencapai kesuksesan dengan usaha yang telah direncanakan.

Tidak berpengaruhnya norma subyektif terhadap munculnya potensi intensi berwirausaha dapat dikarenakan oleh berbagai sebab. Mahasiswa pada umumnya masih tergantung pada orang disekelilingnya seperti orang tua, teman, atau dosen. Sehingga, biasanya semakin tinggi dukungan pada mahasiswa untuk berwirausaha, maka akan semakin tinggi pula rasa percaya diri mahasiswa untuk berwirausaha. Sehingga, dapat memberikan pengaruh terhadap intensi berwirausahanya. Namun, berbeda dengan temuan pada penelitian ini. Bahwa ternyata norma subyektif tidak memberikan pengaruh yang signifikan terhadap intensi berwirausaha mahasiswa. Hal ini dimungkinkan bahwa tingkat ketergantungan sebagian mahasiswa Program Studi Pendidikan Ekonomi FKIP Universitas Jember terhadap orang disekelilingnya tidak terlalu besar. Oleh karena itu, sebagian besar mahasiswa tidak menjadikan norma subyektif sebagai salah satu elemen yang menjadi pertimbangan mereka dalam memutuskan untuk berwirausaha.

Sehingga, dapat disimpulkan bahwa dalam penelitian ini teori Ajzen dan Fishbein "The Theory of Planned Behavior" (dalam Baron dan Byrne, 2004) yang mengungkapkan bahwa norma subyektif menjadi salah satu prediktor pengaruh intensi tidak terbukti. Norma subyektif tidak dapat terbukti menjadi prediktor yang mempengaruhi intensi berwirausaha pada mahasiswa Program Studi Pendidikan Ekonomi FKIP Universitas Jember.

Hipotesis keempat yang diajukan dalam penelitian ini ditolak. Berdasarkan hasil penelitian diperoleh hasil yang menunjukkan bahwa norma subyektif tidak terbukti mempunyai pengaruh yang signifikan terhadap perilaku berwirausaha mahasiswa. Hasil tersebut dapat dilihat dari nilai koefisien jalur norma subyektif $\left(\mathrm{X}_{2}\right)$ terhadap perilaku berwirausaha $(\mathrm{Y})$. Hal ini berarti bahwa norma subyektif 
mahasiswa Program Studi Pendidikan Ekonomi FKIP Universitas Jember ternyata tidak terbukti mempengaruhi tingkat perilaku berwirausahanya.

Hasil penelitian ini bertentangan dengan penelitian sebelumnya yaitu penelitian dari Wijaya (2008) yang menerangkan bahwa norma subyektif merupakan salah satu prediktor yang berpengaruh positif terhadap perilaku berwirausaha. Berbeda dengan hasil penelitian Wijaya yang menjelaskan bahwa pelaku usaha di DIY dan Jawa Tengah yang mendirikan UKM ternyata salah satunya dipengaruhi oleh prediktor norma subyektif. Ternyata tidak berlaku pada penelitian ini, mahasiwa tidak menjadikan norma subyektif sebagai salah satu pertimbangan ketika memutuskan untuk berwirausaha.

Norma subyektif tidak berpengaruh signifikan terhadap intensi berwirausaha. Temuan dalam penelitian ini indikator pada variabel norma subyektif rata-rata memiliki sumbangan rendah terhadap variabel norma subyektif, di antaranya paling rendah dipengaruhi oleh indikator kelima yaitu keyakinan dukungan dari orang yang dianggap penting. Hal ini dapat ditunjukkan dari hasil temuan bahwa hanya sebagian kecil mahasiswa saja yang sering mengikuti seminar yang memberikan motivasi dan pengetahuan kewirausahaan yang diadakan oleh para pengusaha atau lembaga-lembaga yang bergerak di bidang wirausaha.

Selain itu, juga didukung oleh temuan bahwa pada variabel perilaku berwirausaha paling rendah dipengaruhi oleh indikator kedua yaitu tindakan nyata telah menjalankan usaha. Hal ini dapat ditunjukkan dari hasil temuan bahwa sebagian besar mahasiswa masih belum memiliki usaha sendiri, sebagian besar mahasiswa belum memiliki usaha yang berkembang, dan sebagian besar mahasiswa juga belum memiliki usaha yang dikelola sendiri.

Sehingga, dapat disimpulkan bahwa dalam penelitian ini teori Ajzen dan Fishbein "The Theory of Planned Behavior" (Baron \& Byrne, 2004) yang mengungkapkan bahwa norma subyektif menjadi salah satu prediktor pengaruh perilaku tidak terbukti. Norma subyektif ternyata tidak dapat terbukti menjadi prediktor yang mempengaruhi perilaku berwirausaha pada mahasiswa Program Studi Pendidikan Ekonomi FKIP Universitas Jember.

Hipotesis kelima yang diajukan dalam penelitian ini diterima. Berdasarkan hasil penelitian diperoleh hasil yang menunjukkan bahwa efikasi diri mempunyai pengaruh yang signifikan terhadap intensi berwirausaha mahasiswa. Hasil tersebut dapat dilihat dari nilai koefisien jalur efikasi diri $\left(\mathrm{X}_{3}\right)$ terhadap intensi berwirausaha (Z). Hal ini berarti bahwa efikasi diri mahasiswa Program Studi Pendidikan Ekonomi FKIP Universitas Jember mempengaruhi tingkat intensi berwirausahanya.

Hasil penelitian ini mendukung hasil penelitian-penelitian sebelumnya di antaranya yang dilakukan oleh Urban, Jurie, dan Rina (2008) dalam penelitiannya menyimpulkan bahwa efikasi diri memberikan pengaruh terhadap niat kewirausahaan pada 210 responden etnis yang berbeda di Afrika Selatan. Sedangkan Wang, Wei, dan John (2011) menyimpulkan bahwa efikasi diri memberikan pengaruh positif bagi pembentukan intensi berwirausaha bagi mahasiswa Cina dan AS, meskipun ada beberapa perbedaan yang signifikan antara mahasiswa perguruan tinggi di Cina dan di AS. Dari penelitian Dwijayanti (2012) menyimpulkan bahwa Efikasi diri juga berpengaruh signifikan terhadap intensi berwirausaha mahasiswa. 
Indarti dan Rokhima (2008) dalam penelitiannya menjelaskan bahwa berdasarkan pendapat Betz dan Hacket efikasi diri akan karir seseorang adalah domain yang menggambarkan pendapat pribadi seseorang dalam hubungannya dengan proses pemilihan dan penyesuaian karir. Dengan demikian, efikasi diri akan karir seseorang dapat menjadi faktor penting dalam penentuan apakah intensi kewirausahaan seseorang terbentuk pada tahapan awal seseorang memulai karirnya. Lebih lanjut Betz dan Hacket menyatakan bahwa semakin tinggi tingkat efikasi diri seseorang pada kewirausahaan di masa-masa awal seseorang dalam berkarir, maka akan semakin kuat intensi kewirausahaan yang dimilikinya.

Hal ini juga mendukung penelitian terdahulu dari Andika dan Iskandarsyah (2012) yang menyimpulkan bahwa efikasi diri berpengaruh signifikan terhadap intensi berwirausaha mahasiswa. Penelitian lain dari Sarwoko (2011) juga menyimpulkan bahwa intensi berwirausaha dipengaruhi oleh di antaranya yaitu efikasi diri, dimana pengaruhnya positif. Semakin tinggi rasa percaya diri dan kematangan mental maka semakin tinggi pula intensi berwirausahanya. Keyakinan pribadi yang dicerminkan dalam bentuk efikasi diri dapat menggambarkan sejauh mana kemampuan mahasiswa dalam memulai bisnis baru. Rasa kepercayaan diri mahasiswa tercermin ketika dia merasa mampu dan mempunyai keinginan untuk memulai bisnis dan mengarah ke arah keberhasilan. Sehingga, dapat disimpulkan bahwa teori Ajzen dan Fishbein "The Theory of Planned Behavior" (Baron \& Byrne, 2004) yang mengungkapkan bahwa efikasi diri menjadi salah satu prediktor pengaruh intensi terbukti. Efikasi diri ternyata terbukti menjadi prediktor yang mempengaruhi intensi berwirausaha pada mahasiswa Program Studi Pendidikan Ekonomi FKIP Universitas Jember.

Hipotesis keenam yang diajukan dalam penelitian ini diterima. Berdasarkan hasil penelitian diperoleh hasil yang menunjukkan bahwa efikasi diri mempunyai pengaruh yang signifikan terhadap perilaku berwirausaha mahasiswa. Hasil tersebut dapat dilihat dari nilai koefisien jalur efikasi diri $\left(\mathrm{X}_{3}\right)$ terhadap perilaku berwirausaha (Y). Hal ini berarti bahwa efikasi diri mahasiswa Program Studi Pendidikan Ekonomi FKIP Universitas Jember mempengaruhi tingkat perilaku berwirausahanya.

Hasil penelitian ini mendukung hasil penelitian-penelitian sebelumnya di antaranya penelitian yang dilakukan oleh Wijaya (2008) yang menerangkan bahwa efikasi diri merupakan salah satu prediktor yang berpengaruh positif terhadap perilaku berwirausaha. Penelitian Wong dan Lena (2005) yang menyimpulkan bahwa variabel persepsi seperti di antaranya efikasi diri memiliki pengaruh yang signifikan di semua aspek kegiatan kewirausahaan di Singapura, efikasi diri memiliki dampak terbesar. Sedangkan penelitian Lee, Poh Kam, Bee Leng, dan Jennifer (2006) menyimpulkan bahwa efikasi diri memiliki pengaruh terbesar pada kewirausahaan di Singapura, Hong Kong, dan Taiwan.

Efikasi diri berpengaruh signifikan terhadap perilaku berwirausaha mahasiswa Program Studi Pendidikan Ekonomi FKIP Universitas Jember didukung oleh temuan pada variabel efikasi diri dalam penelitian ini paling dominan didukung oleh indikator keempat yaitu merasa mampu memulai usaha. Hal ini dapat ditunjukkan dari hasil temuan bahwa sebagian mahasiswa yakin memiliki kemampuan pengetahuan dasar untuk memulai usaha baru, dan mahasiswa yakin mampu untuk memulai bisnis suatu hari nanti. 
Selain itu, juga didukung oleh temuan pada variabel perilaku berwirausaha paling dominan didukung oleh indikator ketiga yaitu rencana pengembangan usaha yang ada masuk dalam kategori sedang. Hal ini dapat ditunjukkan dari hasil temuan bahwa sebagian dari mahasiswa sudah merencanakan untuk mengembangkan usaha yang dimiliki untuk kedepannya.

Dapat dilihat bahwa pengaruh efikasi diri terhadap perilaku berwirausaha mahasiswa memiliki pengaruh paling dominan. Sehingga, semakin tinggi rasa percaya diri mahasiswa dan kematangan mentalnya maka semakin tinggi pula perannya untuk membangkitkan munculnya perilaku berwirausaha mahasiswa. Seperti pendapat dari Baron dan Byrne (2004) yang menjelaskan bahwa keyakinan akan kemampuan individu untuk melakukan suatu tindakan merupakan prediktor yang signifikan terhadap terbentuknya perilaku individu.

Hipotesis ketujuh yang diajukan dalam penelitian ini ditolak. Berdasarkan hasil penelitian diperoleh hasil yang menunjukkan bahwa intensi berwirausaha tidak terbukti mempunyai pengaruh yang signifikan terhadap perilaku berwirausaha mahasiswa. Hasil tersebut dapat dilihat dari nilai koefisien jalur intensi berwirausaha $(\mathrm{Z})$ terhadap perilaku berwirausaha (Y). Hal ini berarti bahwa intensi berwirausaha mahasiswa Program Studi Pendidikan Ekonomi FKIP Universitas Jember tidak mempengaruhi tingkat perilaku berwirausahanya.

Hasil penelitian ini bertentangan dengan pendapat dan hasil penelitian sebelumnya di antaranya menurut Dwijayanti (2012) yang menyatakan bahwa intensi berwirausaha merupakan faktor motivasional yang mendorong seseorang dalam menampilkan perilaku kewirausahaan. Sehingga, seseorang dengan intensi untuk memulai usaha akan memiliki kesiapan dan kemajuan yang lebih baik dalam usaha yang dijalankan (Indarti \& Rokhima, 2008). Selain itu, hasil penelitian ini juga bertentangan dengan pendapat Suharti dan Hani (2011) yang menyatakan bahwa intensi yang berkaitan dengan kewirausahaan diyakini terbukti dapat menjadi cerminan dari perilaku kewirausahaan yang sesungguhnya. Sehingga, intensi untuk berwirausaha dapat menjadi langkah awal dalam pembentukan usaha baru. Hal tersebut senada dengan penjelasan Indarti dan Rokhima (2008) bahwa menurut pemikiran Krueger dan Carsrud intensi terbukti menjadi prediktor yang terbaik bagi perilaku kewirausahaan.

Intensi berwirausaha tidak berpengaruh signifikan terhadap perilaku berwirausaha mahasiswa Program Studi Pendidikan Ekonomi FKIP Universitas Jember. Temuan dalam penelitian ini indikator pada variabel intensi berwirausaha yang memiliki rata-rata sumbangan terendah yaitu pada indikator ketiga yaitu melakukan perencanaan untuk memulai usaha. Hal ini dapat ditunjukkan dari hasil temuan bahwa mahasiswa mempunyai gambaran tentang modal dasar berwirausaha, mahasiswa memiliki pengetahuan tentang lokasi strategis berwirausaha berdasarkan pengamatan, mahasiswa memiliki rencana yang jelas untuk menekuni bidang usaha tertentu dimasa mendatang, keinginan berwirausaha telah didukung oleh perencanaan yang matang, dan mahasiswa memiliki keyakinan dapat mencapai kesuksesan dengan usaha yang telah direncanakan.

Selain itu, juga didukung oleh temuan bahwa pada variabel perilaku berwirausaha paling rendah dipengaruhi oleh indikator kedua yaitu tindakan nyata telah menjalankan usaha. Hal ini dapat ditunjukkan dari hasil temuan bahwa sebagian besar mahasiswa masih belum memiliki usaha sendiri, sebagian besar 
mahasiswa belum memiliki usaha yang berkembang, dan sebagian besar mahasiswa juga belum memiliki usaha yang dikelola sendiri.

Hipotesis kedelapan yang diajukan dalam penelitian ini juga ditolak. Berdasarkan hasil penelitian diperoleh hasil yang menunjukkan bahwa intensi berwirausaha tidak terbukti memediasi sikap kewirausahaan terhadap perilaku berwirausaha mahasiswa. Hasil tersebut dapat dilihat dari nilai t hitung koefisien tidak langsung yang menunjukkan bahwa pengaruh sikap kewirausahaan $\left(\mathrm{X}_{1}\right)$ terhadap perilaku berwirausaha $(\mathrm{Y})$ melalui intensi berwirausaha $(\mathrm{Z})$ tidak signifikan.

Hasil penelitian ini bertentangan dengan teori Fishbein dan Ajzen yang menyatakan bahwa intensi merupakan salah satu fungsi dari sikap terhadap perwujudan perilaku dalam situasi tertentu. Selain itu, hasil penelitian ini juga bertentangan dengan pendapat lain dari Ajzen dan Fishbein (Baron \& Byrne, 2004) yang menerangkan bahwa sebuah perilaku dengan keterlibatan tinggi membutuhkan keyakinan dan evaluasi di antaranya untuk menumbuhkan sikap dengan intensi sebagai mediator pengaruh yang berdampak pada suatu perilaku tertentu.

Ternyata Intensi berwirausaha tidak terbukti memediasi sikap kewirausahaan terhadap perilaku berwirausaha mahasiswa. Sikap kewirausahaan mendapat sumbangan terendah dari indikator kedua yaitu berfikir kreatif dan inovatif. Hal ini dapat ditunjukkan dari temuan bahwa sebagian mahasiswa saja yang memiliki keinginan menerapkan ide-ide kreatif dan inovatif dalam berwirausaha, sebagian mahasiswa saja yang selalu aktif bertanya dan berdiskusi saat menempuh mata kuliah kewirausahaan untuk menggali pengetahuan dan ide kreatif dalam berwirausaha, dan sebagian mahasiswa menginginkan adanya caracara baru dalam menyelesaikan sesuatu. Disini intensi berwirausaha tidak dapat menjadi mediasi yang baik, karena ternyata ditemukan bahwa sebagian besar mahasiswa masih belum memiliki usaha sendiri, sebagian besar mahasiswa belum memiliki usaha yang berkembang, dan sebagian besar mahasiswa juga belum memiliki usaha yang dikelola sendiri.

Berdasarkan pembahasan tersebut dijelaskan bahwa untuk mencapai tingkat perilaku berwirausaha yang tinggi tidak perlu melalui mediator peningkatan intensi berwirausaha. Oleh karena itu, lebih baik langsung dari peningkatan variabel sikap kewirausahaannya.

Hipotesis kesembilan yang diajukan dalam penelitian ini ditolak. Berdasarkan hasil penelitian diperoleh hasil yang menunjukkan bahwa intensi berwirausaha tidak terbukti memediasi norma subyektif terhadap perilaku berwirausaha. Hasil tersebut dapat dilihat dari nilai t hitung koefisien tidak langsung yang menunjukkan bahwa pengaruh norma subyektif $\left(\mathrm{X}_{2}\right)$ terhadap perilaku berwirausaha $(\mathrm{Y})$ melalui intensi berwirausaha $(\mathrm{Z})$ tidak signifikan.

Hasil penelitian ini bertentangan dengan teori bertentangan dengan teori Fishbein dan Ajzen (Dayakisni \& Hudaniah, 2006) yang menyatakan bahwa intensi merupakan salah satu fungsi dari norma-norma yang berpengaruh pada perilaku dan motivasi seseorang untuk mematuhi norma-norma tersebut. Selain itu, penelitian ini juga bertentangan dengan pendapat lain dari Ajzen dan Fishbein (Baron \& Byrne, 2004) yang menerangkan bahwa sebuah perilaku dengan keterlibatan tinggi membutuhkan keyakinan dan evaluasi untuk menumbuhkan di 
antaranya norma subyektif dengan intensi sebagai mediator pengaruh yang berdampak pada suatu perilaku.

Intensi berwirausaha tidak terbukti memediasi norma subyektif terhadap perilaku berwirausaha mahasiswa. Norma subyektif mendapat sumbangan terendah dari indikator kelima yaitu keyakinan dukungan dari orang yang dianggap penting. Hal ini dapat ditunjukkan dari hasil temuan bahwa hanya sebagian kecil mahasiswa saja yang sering mengikuti seminar yang memberikan motivasi dan pengetahuan kewirausahaan yang diadakan oleh para pengusaha atau lembaga-lembaga yang bergerak di bidang wirausaha. Disini intensi berwirausaha tidak dapat menjadi mediasi yang baik, karena ternyata ditemukan bahwa sebagian besar mahasiswa masih belum memiliki usaha sendiri, sebagian besar mahasiswa belum memiliki usaha yang berkembang, dan sebagian besar mahasiswa juga belum memiliki usaha yang dikelola sendiri.

Berdasarkan pembahasan tersebut dijelaskan bahwa untuk mencapai tingkat perilaku berwirausaha yang tinggi tidak perlu melalui mediator peningkatan intensi berwirausaha. Oleh karena itu, lebih baik langsung dari peningkatan variabel norma subyektif.

Hipotesis kesepuluh yang diajukan dalam penelitian ini ditolak. Berdasarkan hasil penelitian diperoleh hasil yang menunjukkan bahwa intensi berwirausaha tidak terbukti memediasi efikasi diri terhadap perilaku berwirausaha. Hasil tersebut dapat dilihat dari nilai $\mathrm{t}$ hitung koefisien tidak langsung yang menunjukkan pengaruh bahwa efikasi diri $\left(\mathrm{X}_{3}\right)$ terhadap perilaku berwirausaha (Y) melalui intensi berwirausaha (Z) tidak signifikan.

Intensi berwirausaha tidak terbukti memediasi efikasi diri terhadap perilaku berwirausaha mahasiswa. Efikasi diri mendapat sumbangan terendah dari indikator ketiga yaitu kematangan mental dalam berwirausaha. Hal ini dapat ditunjukkan dari hasil temuan bahwa hanya sebagian mahasiswa saja yang yakin memiliki kesiapan mental untuk menekuni wirausaha setelah lulus kuliah. Disini intensi berwirausaha tidak dapat menjadi mediasi yang baik, karena ternyata ditemukan bahwa sebagian besar mahasiswa masih belum memiliki usaha sendiri, sebagian besar mahasiswa belum memiliki usaha yang berkembang, dan sebagian besar mahasiswa juga belum memiliki usaha yang dikelola sendiri.

Berdasarkan pembahasan dijelaskan bahwa untuk mencapai tingkat perilaku berwirausaha yang tinggi tidak perlu melalui mediator peningkatan intensi berwirausaha. Oleh karena itu, lebih baik langsung dari peningkatan variabel efikasi diri.

\section{SIMPULAN}

Berdasarkan hasil penelitian dan pembahasan yang telah diuraikan, maka dapat disimpulkan bahwa sesuai model penelitian sikap kewirausahaan dan efikasi diri berpengaruh signifikan terhadap intensi berwirausaha. Sikap kewirausahaan dan efikasi diri berpengaruh signifikan terhadap perilaku berwirausaha. Sedangkan, norma subyektif tidak berpengaruh langsung baik terhadap intensi berwirausaha maupun perilaku berwirausaha. Intensi berwirausaha juga tidak berpengaruh langsung terhadap perilaku berwirausaha. Demikian juga dengan sikap kewirausahaan, norma subyektif dan efikasi diri juga tidak berpengaruh signifikan terhadap perilaku berwirausaha melalui intensi berwirausaha. 
Temuan dari penelitian ini yaitu bahwa variabel intervening berupa intensi berwirausaha tidak terbukti memediasi variabel independen yaitu sikap kewirausahaan, norma subyektif, dan efikasi diri terhadap variabel dependen perilaku berwirausaha. Hal ini berarti sikap kewirausahaan, norma subyektif dan efikasi diri lebih kuat mempengaruhi secara langsung terhadap perilaku berwirausaha tanpa harus melewati intensi berwirausaha. Sehingga, direkomendasikan pembelajaran kewirausahaan sebaiknya lebih ditekankan pada pengaruh variabel independen terhadap variabel dependen secara langsung. Di antaranya agar lebih efektif, pembelajaran sebaiknya lebih difokuskan pada pendekatan praktek bukan hanya sekedar teoritis.

\section{DAFTAR RUJUKAN}

Andika, Manda, \& Iskandarsyah Madjid, 2012. Analisis Pengaruh Sikap, Norma Subyektif, dan Efikasi Diri terhadap Intensi Berwirausaha pada Mahasiswa Fakultas Ekonomi Universitas Syiah Kuala. EcoEntrepreneurship Seminar and Call for Paper, Fakultas Ekonomi, Universitas Negeri Semarang. (PP:190 - 197).

Baron, Robert A, \& Donn Byrne, 2004. Psikologi Sosial Jilid 1 (Edisi Ke Sepuluh). Jakarta : Erlangga.

Dayakisni, Tri, \& Hudaniah, 2006. Psikologi Sosial (Edisi Revisi). Malang: UMM Press.

Dwijayanti, Renny, 2012. Pengaruh Norma Subyektif, Sikap Kewirausahaan dan Efikasi Diri terhadap Intensi Berwirausaha Mahasiswa. (Tesis, Magister Pendidikan Ekonomi tidak dipublikasikan). Universitas Negeri Malang.

Indarti, Nurul, \& Rokhima Rostiani, 2008. Intensi Kewirausahaan Mahasiswa: Studi Perbandingan Antara Indonesia, Jepang dan Norwegia. The best paper award CFP JEBI 2008 Diterbitkan pada: Jurnal Ekonomika dan Bisnis Indonesia, Vol. 23, No. 4.

Lee, Lena., Poh Kam Wong., Bee Leng Chua, \& Jennifer Chen, 2006. Antecedents for Entrepreneurial Propensity : Findings from Singapore, Hong Kong and Taiwan. MPRA Paper No. 594, (PP: 1 - 53).

Sarwoko, Endi, 2011. Kajian Empiris Entrepreneur Intention Mahasiswa. Jurnal Ekonomi Bisnis, TH. 16, No. 2, (PP:126 - 135).

Sugiyono, 2011. Metode Penelitian Kuantitatif Kualitatif dan R\&D. Bandung : Alfabeta.

Suharti, Lieli, \& Hani Sirine, 2011. Faktor-Faktor yang Berpengaruh terhadap Niat Kewirausahaan (Entrepreneurial Intention) Studi terhadap Mahasiswa Universitas Kristen Satya Wacana, Salatiga. Jurnal Manajemen dan Kewirausahaan, Vol. 13, No. 2, (PP:124 - 134).

Sukmadinata, Nana Syaodih, 2012. Metode Penelitian Pendidikan. Bandung: Remaja Rosdakarya.

Urban, Boris., Jurie J Van Vuuren, \& Rina H Owen, 2008. Antecedents to Entrepreneurial Intentions : Testing for Measurement Invariance for Cultural Values, Attitudes and Self-Efficacy Beliefs Across Ethnic Groups. SA Journal of Human Resource Management, Vol. 6 No. 1, (PP: 1 - 9). 
Wang, Wenjun., Wei Lu, \& John Kent Millington, 2011. Determinants of Entrepreneurial Intention Among College Students in China and USA. Journal of Global Entrepreneurship Research, Vol. 1 No. 1, (PP: 35 - 44).

Wawan, A \& Dewi, M., 2011. Teori dan Pengukuran Pengetahuan, Sikap dan Perilaku Manusia. Yogyakarta : Nuha Medika.

Wibowo, Agus, 2011. Pendidikan Kewirausahaa (Konsep dan Strategi). Yogyakarta: Pustaka Pelajar.

Wijaya, Tony, 2008. Kajian Model Empiris Perilaku Berwirausaha UKM DIY dan Jawa Tengah. Jurnal Manajemen dan Kewirausahaan, Vol. 10 No. 2, (PP: 93 - 104).

Wong, Poh-Kam \& Lee, Lena, 2005. Antecedents for Entrepreneurial Propensity in Singapore. Entrepreneurship Centre, National University of Singapore. Reference No. : WP2005-12, (PP: 1 - 41). 